\title{
Voz das Crianças / Children's Voices
}

https://doi.org/10.21814/uminho.ed.36.58

\section{Amy Hanna e Laura Lundy}

Queen's University of Belfast, Northern Irland, United Kindgom 



\section{Voz das Crianças}

A noção de "voz" tem sido usada como um legitimador poderoso na infância, sublinhado pelo conceito de empoderamento: permitindo que as crianças partilhem os seus pontos de vista e opiniões; e que participem na tomada de decisões. É utilizado na investigação da infância de modo variado, mas mais comummente como um nome que representa, ora as perspetivas das crianças sobre as suas vidas, ora o processo que captura as visões e experiências das crianças, ou ambas. Ao longo do tempo, o termo voz das crianças tem evoluído desde a simples escuta das crianças à sua participação direta em processos de investigação, até ao uso de metodologias de investigação que refletem as crianças como peritas nas suas próprias vidas, envolvendo-as ao longo desses processos.

O termo "voz" tornou-se omnipresente na investigação da infância. O conceito de voz das crianças foi crescentemente contestado, por exemplo, pelos pós-estruturalistas e os que trabalham no campo dos direitos das crianças. Além disso, um conjunto de tensões têm surgido entre os académicos em Estudos da Infância que têm questionado a autenticidade e representatividade das vozes das crianças, e a influência de poder entre adultos e crianças em processos que procuram não apenas as vozes das crianças, mas também a sua produção.

O termo "voz" pode ser enganador de várias formas. Por exemplo, implica uma voz singular que não reconhece as complexas subjetividades individuais, o contexto ou as disparidades de poder entre adultos e crianças. Alguns autores têm sugerido que é necessário considerar não apenas o papel do poder, mas, também, do contexto, nos processos que informam as vozes das crianças. A assunção de que é possível "capturar" as vozes autênticas ou mesmo uma "voz" única imutável que permanece igual ao longo do tempo. Ao procurar exclusivamente o falado, omitimos o não dito, e a oportunidade de ir para lá significados superficiais procurando as possibilidades de uma leitura das vozes mais matizadas (Lewis, 2010; Spyrou, 2016).

Spyrou (2016) argumenta que é nestes silêncios diversos que podemos ver como é que as crianças se posicionam num encontro investigativo, e em relação a assuntos específicos. É necessário prestar atenção particular às 
preferências dos jovens pelo silêncio, e mobilizar procedimentos cuidadosos que facilitem essas vozes do silêncio, uma vez que diferentes formas e práticas de silêncio podem ser expressões de voz (Lewis, 2010). Em vez de "dar" uma voz aos jovens, é necessário refletir nos processos através dos quais essas "vozes" são produzidas, e ir para além das reivindicações de autenticidade para reformular a voz num continuum entre aquilo que é, literalmente, vocalizado e aquilo que é dito silenciosamente.

Na perspetiva dos direitos das crianças, o uso do termo "voz" atraiu um conjunto misto de respostas. Ele é largamente utilizado como uma abreviatura do artigo $12 .^{\circ}$ da Convenção sobre os Direitos da Criança - o direito da criança a ter as suas perspetivas em consideração em todos os assuntos que a afetam, entrou na lingua franca dos profissionais que trabalham com crianças em áreas como educação, saúde e assistência social, bem como dos investigadores da infância. No entanto, Lundy (2007) advertiu que o uso do termo "voz" como substituto do artigo $12 .{ }^{\circ}$ dilui as obrigações e prejudica, potencialmente, a implementação dos direitos humanos da criança. Assim, sugere que para além de "voz", à criança se proporcione "espaço", "audição" e "influência". A partir de uma perspetiva centrada nos direitos, atender às vozes das crianças significa mais do que procurar ou obter as visões da criança, mas também assegurar que estas são levadas a sério por aqueles que detêm poder para produzir mudanças efetivas nas suas vidas.

Em suma, o conceito de "voz das crianças" foi transformador para os investigadores da infância. Teve um impacto profundo, orientando os adultos na procura e captura das experiências das crianças, apontando todos os que procuram compreender as vidas das crianças para elas permitindo, assim, que sejam envolvidas como criadoras de significado nas suas próprias vidas. Encorajou quer o desenvolvimento (e crítica) de um conjunto de métodos participativos de investigação, incluindo muitas abordagens criativas, desafiando assunções sobre se as crianças devem ou não ser envolvidas na investigação, que procura entender as suas vidas, quer a criação de um roteiro para os que escolham esse caminho. $O$ seu poder e impacto na investigação da infância não podem ser subestimados, nem as suas limitações. Ele funciona melhor como um ponto de partida para os investigadores da infância, encorajando processos de comunicação direta com crianças bem como a sua participação em processos de investigação. No entanto, requer cautela, crítica e reflexividade: não existe uma; um modo único de a comunicar; nem um método perfeito para a capturar. 


\section{Children's Voice}

The notion of "voice" has been used as a powerful legitimator in childhood, underlined by the concept of empowerment: enabling children to share their views and opinions; and to participate in decision-making. It is used in childhood research in a variety of ways, but most commonly as a noun that represents either children's perspectives on their own lives or the process that captures children's views and experiences or both. Over time, the term children's voice has developed from simply listening to children directly as participants in research studies, to using methodologies that reflect children as experts in their own lives and involving them throughout research processes. The term "voice" has become ubiquitous in childhood research. The concept of children's voice has become increasingly contested, however, for example, by post-structuralists and those in the field of children's rights. Moreover, a number of tensions have emerged from scholars in childhood studies who have questioned the perceived authenticity and representation of children's voices, and the influence of power between adults and children in processes, which not only seek children's voices, but also produce them.

The term "voice" can be misleading in a number of respects. For example, it implies a singular voice that does not acknowledge complex individual subjectivities, context, or power disparities between adults and children. Some have suggested that it is necessary to consider not only the role of power, but also context, in processes that inform children's voices. The assumption is that it is possible to "capture" the authentic voices or indeed one single immutable "voice" that remains the same over time. By exclusively seeking the spoken, we omit the unspoken, and the opportunity to go beyond surface meanings towards the possibilities for a more nuanced reading of voice (Lewis, 2010; Spyrou, 2016).

Spyrou (2016) argues that it is in their various silences that we see how children position themselves within a research encounter, and in relation to specific subjects. It is necessary to pay careful attention to the preference of young people for silence and use careful procedures to facilitate these voices of silence because many forms and practices of silence may be expressions of voice (Lewis, 2010). Instead of "giving" young people a voice, it is necessary to reflect on the processes through which these "voices" are produced, and to move beyond claims of authenticity to reframe voice on a continuum between what is voiced literally, and what is voiced silently. 
From a children's rights perspective, the use of the term "voice" has attracted a mixed set of responses. It is widely used as an abbreviation for Article 12 of the UN Convention on the Rights of the Child - the child's right to have their views given due weight in all matters affecting them and has entered the lingua franca of professionals who work with children in education, health and social care as well as childhood researchers. However, Lundy (2007) has cautioned that the use of the term "voice" as a substitute for Article 12 dilutes the obligation and potentially undermines the implementation of the child's human right. She suggests that in addition to "voice", the child must be afforded "space", "audience" and "influence". From a rights-based perspective, attending to children's voice means more than seeking or capturing children's views but also ensuring that they are taken seriously by those with the power to effect change in their lives.

In summary, the concept of "children's voice" has been transformative for childhood researchers. It has had a profound impact, directing adults to seek and capture children's experiences by signposting those who wish to understand children's lives directly to children themselves and thus enabling them to be involved as the meaning-makers in their own lives. It has encouraged both the development (and critique) of a range of participatory research methods, including many creative approaches, challenging assumptions about whether children can or should be involved in the research which seeks to understand their lives and providing a roadmap for those who choose to do so. Its power and impact on childhood research cannot be underestimated but nor should its limitations. It works best as an entry point for childhood researchers, encouraging direct communication with children as well as their participation in research processes. However, it requires caution, critique and reflexivity: there is not one voice; not one way in which it is communicated; and not one perfect method for capturing it.

\section{Referências / References}

Lewis, A. (2010). Silence in the context of 'child voice'. Children \& Society, 24(1), 14-23.

Lundy, L. (2007). 'Voice 'is not enough: conceptualising Article 12 of the United Nations Convention on the Rights of the Child. British educational research journal, 33(6), 927-942.

Spyrou, S. (2016). Researching children's silences: Exploring the fullness of voice in childhood research. Childhood, 23(1), 7-21. 